\title{
IMPACT OF THE LABOR MARKET POLICIES FOR ENSURING EMPLOYMENT
}

\section{Venelin Terziev}

Corresponding Member of the Russian Academy of Natural History, Moscow, Russia, Prof. D.Sc. (Ec.), D.Sc. (National Security), D.Sc. (Social Activities), Ph.D., National Military University, Veliko Tarnovo, Bulgaria; University of Rousse, Rousse, Bulgaria, terziev@skmat.com

\begin{abstract}
This paper is a result of several years of efforts related to the study of the social policies applied on unemployment and employment and a study of the impact of the National Program „From Social Assistance to Employment" of the national labor market. The possibilities for social integration and reintegration of representatives of risk groups have been specially examined.
\end{abstract}

Keywords: social management, unemployment, employment.

\section{INTRODUCTION}

Any form of human activity is related to getting ahead of any specific actions of its understanding in some way, i.e. as a particular program. This is even more important when it comes to organization and coordination of joint actions and activities, managing the whole business in social communities, starting with the smallest and ending with the national.

Compared to the existing political and governing practices, the nature of social programming is characterized by finding and justifying an algorithm for upcoming activities and actions in order to solve societal problems and to achieve the necessary and desired result. Social programming is manifested in various forms: creation of norms, normative or programming forecasting, design, planning, etc.

Justified social norms, solutions and programs containing the outcome (goal) and approach for its reach (methods and procedures for the activity) in the mselves, enable the impact on the processes in a targeted, comprehensive and systematic way.

For many years our society has created a special form of social programming, which basic forms have been the party directives and total government planning. When in the early 90's the system was exhausted, a search of new forms of social programming started, adequate to orientation to a market economy and civil society.

The use of the discovered in Western societies separate, predominantly "liberal" forms of social programming (legal ensuring of social regulation, the combination of "soft" government decisions of 
predictive nature and the very sound system of planning in companies, organizations, etc.), now becomes unsystematic and unprepared, without due regard for the specifics of the Bulgarian society and the specific characteristics of the regions, districts and municipalities.

In this first phase of reforms of all possible means the so called "Shock” method was chosen- which transfers the system from one extreme solution to another, which is also extreme.

The attempt at the national legislative level: the Constitution of the Republic of Bulgaria from 1991- to determine adequate model and reference for the development of Bulgarian society in the absence of clearly defined and legitimized programs- concepts and institutional transformations, did not and could not bring the desired result. Naturally, in these conditions the new „social” laws- the Unemployment Protection and Employment Promotion Act, the Employment Promotion Act, the Compulsory Social Insurance Code, the Social Insurance Code, the Social Assistance Act, the Integration of People with Disabilities Act etc., are bringing more methodical and technological character than are providing social and legal methods for solution in this regard. To some extent this situation is a result of the apparent insufficient general theoretical and methodological development of the problem for social programming as well as the absence of systems, assessing its effectiveness.

The effectiveness assessment that became apparent in the practice of the economic activity, until recently has not been used in the social field or is taken down to simple transfer of the basic principles for the assessment of economic efficiency to social processes. It is vital that today, within the given course of scientific research, the reasoning of the term „efficiency” has substantially been changed by the functioning of public systems. In particular, it is recognized that the principle of effectiveness is not limited to purely economic and market criteria. Nowadays there are all indications that the principle of social efficiency in the nearest global perspective will not only be a means of correcting the social consequences of economic development, but also an active tool for structuring the business itself, the most important prerequisite for achieving sustainable economic effects. We can conclude that in the modern circumstances the principle of social efficiency is realized within the business activity itself. This becomes particularly evident when considering the field of employment of the population, primarily in specific administrative districts and municipalities.

This study is devoted to the problem of testing the effectiveness of social programming as a function of the state social policy (applied at the level of the administrative district and municipality) and the specific forms of its realization (regional targeted social programs) in the field of social protection and employment of the population.

The general concept implies disclosure of the nature of social programming. Moreover, we find in the classics of philosophical thought (Aristotle, Plato, Ibn Khaldun, F. Voltaire, E. Kant, Hegel, Marx and others.) a number of fundamental principles of the dialectical unity between the image and the ways of action, the outpacing nature of the mental image and the way of action in real actions, etc. Certain approaches to the study of social programming in the context of public awareness are contained in the works of modern philosophers.

The social program as the most important part of the socio-cultural process is the subject of research in a number of works of contemporary scholars and scientists. The ratio between the conscious and spontaneous inception in the programming of human activity, the relationship of social programming with scientific prediction and the use of program-target approach in science, programming of socio-economic processes are the basis for research and development. The most important forms of social programming: normative forecasting, social designing and social planning find deep and versatile reasoning in a number of works. The relation between social programming and social technologies was first discovered by K.Poper.

In recent years from the applied norms a separate research tendency aimed at summarizing the positive experience of the work of state social services and the development of a system of recommendations for improving their effectiveness has emerged. Different dimensions of the activity and social effectiveness of social services has been analyzed. Despite the private nature of many of the tested approaches and recommendations, most of the works are pushing the idea of the need to build a complete system for securing the social activity of the activities of state social services and developing an accurate system of criteria for the evaluation of its effectiveness. In this respect we can positively assess the placement of the given problem and the development of common approaches against the analysis of the effectiveness of employment and social protection authorities. However, it should be noted that many of the marked lines intersect each other and many works by different authors in most cases contain related questions.

In addition, neither of these studies aims at theoretical and methodological justification and comprehensive assessment of the social programming. As a concept that is too frequently employed and constantly used in 
the practice of the state government, for the present moment social programming does not imply mandatory comprehensive assessment of the effectiveness of all stages in the development of its product- „social programs". In this connection the assigned objective of integrated assessment of social programming as a function of state power and its effectiveness following the example of regional social programs implemented in individual districts and municipalities is justified.

\section{DETAILS EXPERIMENTAL}

The following tasks have been assigned in compliance with the objective:

- defining the role and place of social programming within the system of sociological categories;

- developing criteria and indicators for the effectiveness of social programs;

- considering the effectiveness of the activity of public employment authorities;

- analyzing the effectiveness of the national regional social protection programs (for employment) of the population in the Republic of Bulgaria, addressing specific regions and municipalities;

- considering the social performance of the activity of employment offices as a body for the implementation of the state employment policy;

- assessing the effectiveness of the project and the interim results of the National Program „From Social Assistance to Employment" for the period 2000 - 2015.

- Subject of the study is the social protection system and ensuring employment of the population in Bulgaria.

Subject of the study is the assessment of the effectiveness of the National Program „From Social Assistance to Employment", its implementation at regional and local level as a means of organization of the bodies for social protection and employment of the population.

The theoretical and methodological bases of research shall be concluded in its comprehensive and systematic approach. This complex (interdisciplinary) approach, suggesting integration of sociological, theoretical and management, socioeconomic and other aspects of the study is related to the system analysis.

Methodologically based on the study are the fundamental ideas of Bulgarian and foreign sociology for the specifics of social efficiency in the activity of subjects of institutional governance, including the state power bodies. Based on them, social governance is seen from the perspective of a system method, being the regulation of the relations between subject and object of management as a purposeful impact on the social system in order to bring its operation and development in accordance with socially significant goals.

Empirical basis. In addition to the theoretical methods, methods of observation and statistical analysis of sociological information have actively been used within the work.

The information sources used in the research project incorporate archival documents from the Ministry of Labor and Social Policy, the National Employment Service (later the Employment Agency), the National Social Assistance Service (later the Social Assistance Agency), the National Statistical Institute, the National Insurance Institute; documentary sources and statistical materials of the bodies of social protection and employment; programs for social support and employment of the population in the Republic of Bulgaria; information materials from the Ministry of Labor and Social Policy, the Employment Agency, the Agency for Social Assistance, the National Institute of Statistics; socio-demographic data of the population, school and university students, the professional qualification structure of employed and unemployed people in the country; materials of sociological studies of the main categories of unemployed people of working age; results of expert surveys of managers and specialists from social protection and employment offices; specific literature on the topic; materials from the media, conferences, meetings, seminars and „round tables” on the issues analyzed in the study. Local observations and impressions have a significant contribution among the information sources, which in combination with the statistical materials and expertise, allow forming an objective picture of the analyzed processes and designing optimal model for measuring the social efficiency of the activities of the Public Employment Services (the Employment Agency, „Regional Employment Services”, „Labor Office” Directorates and their subsidiaries).

The regional principle of study of the social efficiency of the activities of state social offices is selected in connection with the fact that at this level the selected methodologies for assessing the effectiveness are the most representative and specifically represent the relation between the established organization of the subject of management activities (the specific state power body in the region) and the researched subject - 
the national regional social programs.

Scientific novelty lies in the comprehensive evaluation of the effectiveness of the programs for social assistance and the employment programs of the population as specific products of the activity of the state social services in the region, including districts and municipalities. In this regard:

- the role and place of social programming within the system of sociological and economic categories has been defined;

- criteria and indicators for the effectiveness of social programming in the system of social protection and employment of the population have been developed;

- the evaluation criteria for efficient operation of public employment services have been disclosed;

- analysis of the effectiveness of the implementation of a national program at regional and local level has been performed for the first time;

- the social and structural specificity in the activities of employment offices, as an authority for implementation of the state employment policy in different districts and municipalities has been shown;

- a comprehensive evaluation of the content and the interim results of the implementation of the comprehensive program for employment assistance of the population in Bulgaria for the period $2000-2015$ has been conducted for the first time.

The basics of the study consist of the following:

- In the public institutionalization, the role of social programming is defining the norms, as it derives from the decision-making process, it sets out solution priorities and formulates the problems and the resulting tasks.

- The use of a specially developed system of metrics and indicators allows to determine the degree of efficiency of the activity of state social services in their integral significance in the evaluation of the dynamic interrelations in the changes between „internal” and "external” environment in the governance of these areas, and to set up a system of criteria and evaluations of the social efficiency in its individual functional elements.

- The analysis of the efficiency of the regional and local public employment offices and targeted social programs as products of their activity allows the adoption of the following principal points as efficiency criteria: the relevance of the program objectives with the objectives for social development and the needs of the recipients, the existence of prognosis of the socio-economic consequences from the events of the program, the use of modern methods for analysis of the organization and management of the programs accounting the resource, legal and information security of these events, achieving the goals of the program in the most optimal way, defined as the degree for solving social problems with minimum time and minimum level of material losses to society.

- The disclosed deficiencies in the programs for social protection of the population in the country and the respective regions suggest the lack of efficient program-targeted approach for solving social problems. These include insufficient funding, lack of necessary legal and information security for their planning and implementation, lack of project management, real control in the execution of programs and evaluation of their economic efficiency.

- As a result of the analysis of the complex employment program for the population in the country for the period 2000-2015 (National Program „From Social Assistance to Employment”) main drawbacks are defined as follows: At the stage of development of the draft program: the lack of legislative mechanisms for the development and implementation of targeted programs (undeveloped specific criteria and indicators for efficiency assessment of program activities). At the stage of implementation: lack of accurate control mechanisms in the use of budget funds allocated for the program implementation and for compliance of the obtained results with the program objectives. In the stage for summarizing the interim and main results: no calculations have been performed for the final evaluation of the economic efficiency of the results of the program activities and evaluation of the satisfaction of the recipients of the program.

- The functioning of a uniform mechanism for social protection and the provision of employment in the country suggests monitoring of the social sphere, development of a system of program activities, organization of the resource, legal and information security of these events.

The scientific and practical significance of the work is expressed in the fact that the concept of social programming has a direct relation to the implementation of social policies and the implementation of good 
governance practices in the country and the relevant administrative districts and municipalities and allows the specification of an entire line of conditions in normative legal basis for the regulation of social relations.

The results of the sociological and economic analysis allow to determine the content of the principle of social efficiency in the programming part of the activities of regional and local government social services for employment, to offer a comprehensive methodology for sociological analysis and measurement of social performance of these types of activities to identify the most important determinants in the implementation of the present principle, to evaluate and determine the main directions for improving the social performance of the work of the analyzed services.

The results of the study can be used for the compilation of training and work programs, courses related to the foundations of social development, economic sociology, economics and sociology of labor, the development of specialized courses lectured to students in higher education institutions, for additional training of managers and experts from regional and local employment offices („Regional Employment Offices", "Labor Office" directorates and their subsidiaries) in the offices for social protection of the population („Social assistance” directorates), in working with students and university students from professional schools, colleges and universities and others in the development of regional, district and municipal social employment programs (Terziev, Georgiev, 2017, pp. 94-101; Terziev, Georgiev, 2017a, pp. 1418-1437; Terziev, Georgiev, 2017b, pp. 602-606; Terziev, Georgiev, 2017c, pp. 607-610; Terziev, Banabakova, Ilsheva, Georgiev, 2017d, pp. 44-53; Terziev, Banabakova, Ilsheva, Georgiev, 2017e, pp. 138145; Terziev, Banabakova, Georgiev, 2017f, s.64-69; Terziev, Banabakova, Georgiev, 2017g, s.70-75; Terziev, Banabakova, Georgiev, 2017h, s.76-81; Terziev, Banabakova. Georgiev, 2017i, s. 103-106; Terziev, Banabakova., Georgiev, 2017j, s. 100-103; Terziev, Banabakova, Georgiev, 2017k, s. 97-100; Terziev, Banabakova, Georgiev, 2017l, s. 107-110; Terziev, Banabakova, Georgiev, 2017m, s. 111-115; Terziev, Banabakova, Georgiev, 2017n, s. 116-120; Terziev, Banabakova, Georgiev, 2017o, s. 120-124; Terziev, Banabakova, Georgiev, 2017p, s. 125-128; Terziev, Banabakova, Georgiev, 2017q, s. 128-131; Terziev, Banabakova, Georgiev, 2017r, s. 131-135; Terziev, Banabakova, Georgiev, 2017s, s. 135-139; Terziev, Banabakova, Georgiev, 2017t, s. 13-16; Terziev, Banabakova, Georgiev, 2017u, s. 16-19; Terziev, Banabakova, Georgiev, 2017v, s. 20-23).

Approbation of the results of the study. The study results can be implemented:

- in the practice of the public authorities for social protection, support and employment of the population a complex of sociological research has been held on "Investigation on the demanded professions and specialties on the labor market and vocational training programs for the unemployed" and "Sociological monitoring of social offices, related to the selection and recruitment in social programs". The author has participated in the development of instruments and the implementation of "Complex monitoring for compliance with the professional qualification structure of free labor force and jobs in the secondary labor market", the results of the survey were used in the practice of the Ministry of Labor and Social Policy in developing a system for programmed and targeted cost management for the implementation of social programs.

- in the program of numerous national and international conferences, scientific and practical conferences and seminars.

- the most essential implementations and results of the study are reflected in more than 100 scientific publications totaling over 500 printed sheets.

\section{CONCLUSION}

The analysis of the theoretical and methodological issues of social planning allows the proposition of a comprehensive concept of the institutional and governmental foundations of social programming.

The institutional and governmental approach involves detecting the role of social programming as a function of the public institutions, power and government. Moreover, if social programming in an institutional approach brings some norms, in the government it takes the form of a solution. The interaction of social institutions and government systems depends very much on the mechanism of this transformation.

Strategic programming turns to be a major center for transformation of the program norms in the governmental decision, in which promising conceptual solutions are produced based on programtarget principle (approach). Depending on the situations and the instrument that is used by the person receiving the decision, the strategic programs can take the shape of prognosis, projects, plans in various combinations. Different types apply specific range of skills. The „Firm” use of only one of them, in some cases leads to a loss of manageability, spontaneous "self-programming" of the processes and in other cases makes the 
governing system rigid and deprives it from the necessary flexibility and the ability for fast reconstruction of the methods for impact. This is clearly visible in the two crises of the twentieth century- the spontaneous development of market relations in the late 20s, the early 30s in the West (especially in the US) where the system for state programming was virtually absent and the stagnation in the socio-economic development of the USSR, which led to the crisis in the late 80 s and the early 90 s where the government system was „attached” to the total government directives.

The analysis of the interaction of institutional programming, resulting in adequate formation of norms (expressed primarily through legislation) and governmental through the program-target mechanism (through strategic, organizational and competent programming) shows that these essential parts can create efficient enough system of social programming, combining the mechanisms of the market economy with state regulation in the social spher.

We consider necessary the clarification of the different cases in the legislation. In particular, it is necessary to define the concept of social programming (social programs) as a promising structural image and method of action, created for coordinated interaction between the bodies of power, aimed to solve important social problems using the contractors bound by resources and deadlines for the implementation of complex events.

The project approach to solving social problems, which is implicit in the given definition, allows us to assess the effectiveness of the social programs as a use of effective methods for management, concentrated with optimal use of program resources. The concept of social efficiency should not be considered as a separate type (class) but as an organic constituent component /main part/ of any social program.

It is also necessary to adopt national legislation for regional social programming, which has to ensure the unity of the legal and theoretical and methodological foundations for development and support of strategic government programs at national and local level.

In this system a particularly important role is played by the subsystem of target national and social programs, funded by the state budget (under the respective co-ordination) at all levels of the public administration. Its managing role is particularly important in the interaction at different levels (national, regional and local), as well as in the coordination of activities of the various social offices with businesses and public organizations (groups) within a single methodology, forming a unified field of social protection and ensuring effective employment of the population.

Further study of these issues and the development of progressive social technologies will enable more efficient use of the social programming in solving current problems and actions during crises (Terziev, Georgiev, Georgiev, 2017w, pp. 295-300; Terziev, Georgiev, Georgiev, 2017x, pp. 300-305; Terziev, Georgiev, Georgiev, 2017y, pp. 305-311; Terziev, Georgiev, Georgiev, 2017z, pp. 311-317; Terziev, Georgiev, Georgiev, 2017aa, pp. 317-324; Terziev, Georgiev, Georgiev, 2017ab, pp. 324-329; Terziev, Georgiev, Georgiev, 2017ac, pp. 329-335; Terziev, Georgiev, 2018, pp. 452-461; Terziev, Georgiev, 2018a, pp. 6-15; Terziev, Banabakova, Stefanov, Georgiev, 2018b, pp. 267-272; Terziev, Banabakova, Stefanov, Georgiev, 2018c, pp. 79-87).

\section{REFERENCE LIST}

Terziev, V., Georgiev, M. (2017). Active social programs development in Bulgaria: Contemporary challenges and social management instruments. // International Journal of Humanities and Social Science Invention. www.ijhssi.org, 6, 2017, N 1, pp. 94-101, ISSN (Online): 2319 - 7722, ISSN (Print): 2319 7714.

Terziev, V., Georgiev, M. (2017a). The active model of a social programme and ITS strategic advantage. // Medical Teacher. Taylor \& Francis, 39, 2017, N 12 (2), pp. 1418-1437, ISSN: 0142-159X (Print), ISSN: 1466-187X (Online).

Terziev, V., Georgiev, M. (2017b). Highlights of the Evolution of the 'Balanced Scorecard' idea as a model for managing strategy development and control. // IJASOS- International E-journal of Advances in Social Sciences, OCERINT International Organization Center Of Academic Research, 3, 2017, N 8, pp. $602-$ 606, e-ISSN: 2411-183X.

Terziev, V., Georgiev, M. (2017c). Highlights of the evolution of the 'Balanced Scorecard' idea as a model for managing strategy development and control. // SOCIOINT 2017- 4th International Conference on Education, Social Sciences and Humanities 10-12 July 2017- Dubai, UAE, OCERINT- International 
IJASOS- International E-Journal of Advances in Social Sciences, Vol. IV, Issue 12, December 2018

Organization Center of Academic Research, 2017, pp. 607-610, ISBN: 978-605-82433-1-6.

Terziev, V., Banabakova, V., Ilsheva, M. Georgiev, M. (2017d). Motivation and stimulation of workers as a basic aspect of the organization. // Scientific journal «Economics and finance». GPG Publishing Group, Pretoria, South Africa, Challenges and opportunities of scientific thought development: Collection of scientific articles, 2017, pp. 44-53, ISBN 978-0-9942661-6-3.

Terziev, V., Banabakova, V., Ilsheva, M., Georgiev, M. (2017e). Controlling as a management function of the organization. // Scientific journal «Economics and finance». GPG Publishing Group, Pretoria, South Africa, Challenges and opportunities of scientific thought development: Collection of scientific articles, 2017, pp. 138-145, ISBN 978-0-9942661-6-3.

Terziev, V., Banabakova, V., Georgiev, M. (2017f). Razvitie i perestrukturirovanie zanyatosti v Bolgarii s nachala perehoda k raynochnoy ekonomike i v goday evropeyskoy integratsii. // Gromadsyka organizatsiya «Kiïvsykiy ekonomichniy naukoviy tsentr» Zbirnik materialiv vseukraïnsykoï naukovopraktichnoï konferentsiï «Pidpriemnitstvo, buhgaltersykiy oblik ta finansi: natsionalyni osoblivosti ta svitovi tendentsiï» 15-16 veresnya 2017 roku, Kiïv 2017, s.64-69 (Терзиев. В, Банабакова. В., Георгиев, М. Развитие и переструктурирование занятости в Болгарии с начала перехода к рыночной экономике и в годы европейской интеграции. // Громадська організація «Київський економічний науковий центр» Збірник матеріалів всеукраїнської науково-практичної конференції «Підприємництво, бухгалтерський облік та фінанси: національні особливості та світові тенденції» 15-16 вересня 2017 року, Київ 2017, с.64-69).

Terziev, V., Banabakova, V., Georgiev, M. (2017g). Razvitie i perestrukturirovanie zanyatosti v Bolgarii. // Gromadsyka organizatsiya «Kiïvsykiy ekonomichniy naukoviy tsentr» Zbirnik materialiv vseukraïnsykoï naukovo-praktichnoï konferentsiï «Pidpriemnitstvo, buhgaltersykiy oblik ta finansi: natsionalyni osoblivosti ta svitovi tendentsiï» 15-16 veresnya 2017 roku, Kiïv 2017, s.70-75 (Терзиев. B, Банабакова. В., Георгиев, М. Развитие и переструктурирование занятости в Болгарии. // Громадська організація «Київський економічний науковий центр» Збірник матеріалів всеукраїнської науково-практичної конфреренції «Підприємництво, бухгалтерський облік та фрінанси: національні особливості та світові тенденції» 15-16 вересня 2017 року, Київ 2017, с.7075).

Terziev, V., Banabakova, V., Georgiev, M. (2017h). Politiki dlya vozdeystviya i analiz sostoyaniya na raynok truda. // Gromadsyka organizatsiya «Kiïvsykiy ekonomichniy naukoviy tsentr» Zbirnik materialiv vseukraïnsykoï naukovo-praktichnoï konferentsiï «Pidpriemnitstvo, buhgaltersykiy oblik ta finansi: natsionalyni osoblivosti ta svitovi tendentsiï» 15-16 veresnya 2017 roku, Kiïv 2017, s.76-81 (Терзиев. В, Банабакова. В., Георгиев, М. Политики для воздействия и анализ состояния на рынок труда. // Громадська організація «Київський економічний науковий центр» Збірник матеріалів всеукраїнської науково-практичної конференції «Підприємництво, бухгалтерський облік та фінанси: національні особливості та світові тенденції» 15-16 вересня 2017 року, Київ 2017. с.7681).

Terziev, V., Banabakova, V., Georgiev, M. (2017i). Razvitie kontseptsii sotsialynoy ekonomiki. // Materiali dopovidey mizhnarodnoï naukovo - praktichnoï konferentsiï «Suchasni mozhlivosti zabezpechennya sotsialyno-ekonomichnogo rozvitku kraïn» 16 veresnya 2017 roku, Ministerstvo osviti i nauki Ukraïni, Uzhgorodsykiy natsionalyniy universitet, Fakulytet mizhnarodnih ekonomichnih vidnosin, Ekonomichniy fakulytet, Institut derzhavnogo upravlinnya ta regionalynogo rozvitku, Uzhgorod, 2017, s. 103-106, ISBN 978-966-916-348-6 (Терзиев. В, Банабакова. В., Георгиев, М. Развитие концепции социальной экономики. // Матеріали доповідей міжнародної науково - практичної конфреренції «Сучасні можливості забезпечення соціально-економічного розвитку країн» 16 вересня 2017 року, Міністерство освіти і науки України, Ужгородський національний університет, Факультет міжнародних економічних відносин, Економічний фракультет, Інститут державного управління та регіонального розвитку, Ужгород, 2017, с. 103-106, ISBN 978-966-916-348-6).

Terziev, V., Banabakova, V., Georgiev, M. (2017j). Osobennosti, institutsii i znachenie razvitiya raynka truda. Materiali dopovidey mizhnarodnoï naukovo - praktichnoï konferentsiï «Suchasni mozhlivosti zabezpechennya sotsialyno-ekonomichnogo rozvitku kraïn» 16 veresnya 2017 roku, Ministerstvo osviti i nauki Ukraïni, Uzhgorodsykiy natsionalyniy universitet, Fakulytet mizhnarodnih ekonomichnih vidnosin, Ekonomichniy fakulytet, Institut derzhavnogo upravlinnya ta regionalynogo rozvitku, Uzhgorod, 2017, s. 100-103, ISBN 978-966-916-348-6 (Терзиев. В, Банабакова. В., Георгиев, М. Особенности, институции и значение развития рынка труда. Матеріали доповідей міжнародної науково - практичної конференції «Сучасні можливості забезпечення соціально-економічного 
розвитку країн» 16 вересня 2017 року, Міністерство освіти і науки України, Ужгородський національний університет, Факультет міжнародних економічних відносин, Економічний факультет, Інститут державного управління та регіонального розвитку, Ужгород, 2017, с. 100103, ISBN 978-966-916-348-6).

T Terziev, V., Banabakova, V., Georgiev, M. (2017k). Osobennosti, institutsii i znachenie razvitiya raynka truda dlya dostizheniya ustoychivogo ekonomicheskogo i sotsialynogo razvitiya. // Materiali dopovidey mizhnarodnoï naukovo - praktichnoï konferentsiï «Suchasni mozhlivosti zabezpechennya sotsialynoekonomichnogo rozvitku kraïn» 16 veresnya 2017 roku, Ministerstvo osviti i nauki Ukraïni, Uzhgorodsykiy natsionalyniy universitet, Fakulytet mizhnarodnih ekonomichnih vidnosin, Ekonomichniy fakulytet, Institut derzhavnogo upravlinnya ta regionalynogo rozvitku, Uzhgorod, 2017, s. 97-100, ISBN 978-966-916-348-6 (Терзиев. В, Банабакова. В., Георгиев, М. Особенности, институции и значение развития рынка труда для достижения устойчивого экономического и социального развития. // Матеріали доповідей міжнародної науково - практичної конфреренції «Сучасні можливості забезпечення соціально-економічного розвитку країн» 16 вересня 2017 року, Міністерство освіти і науки України, Ужгородський національний університет, Факультет міжнародних економічних відносин, Економічний фракультет, Інститут державного управління та регіонального розвитку, Ужгород, 2017, с. 97-100, ISBN 978-966-916-348-6).

Terziev, V., Banabakova, V., Georgiev, M. (2017I). Sotsialynaye politiki dlya vozdeystviya na raynok truda i razvitie natsionalynoy kontseptsii sotsialynoy ekonomiki. // Strategichni orientiri rozvitku ekonomiki Ukraïni, Mizhnarodna naukovo-praktichna konferentsiya 6-7 zhovtnya 2017 roku, Ministerstvo osviti i nauki Ukraïni, Odesykiy natsionalyniy universitet imeni I. I. Mechnikova, Institut matematiki, ekonomiki ta mehaniki, Kafedra svitovogo gospodarstva i mizhnarodnih ekonomichnih vidnosin, Odesa, 2017, s. 107-110, ISBN 978-617-7326-24-2 (Терзиев, В., Банабакова, В., Георгиев, М. Социальные политики для воздействия на рынок труда и развитие национальной концепции социальной экономики. // Стратегічні орієнтири розвитку економіки України, Міжнародна науково-практична конфреренція 6-7 жовтня 2017 року, Міністерство освіти і науки України, Одеський національний університет імені І. І. Мечникова, Інститут математики, економіки та механіки, Кафедра світового господарства і міжнародних економічних відносин, Одеса, 2017, с. 107-110, ISBN 978-617-732624-2).

Terziev, V., Banabakova, V., Georgiev, M. (2017m). Soderzhanie i Sushtnosty Sotsialynoy Politiki. // Strategichni orientiri rozvitku ekonomiki Ukraïni, Mizhnarodna naukovo-praktichna konferentsiya 6-7 zhovtnya 2017 roku, Ministerstvo osviti i nauki Ukraïni, Odesykiy natsionalyniy universitet imeni I. I. Mechnikova, Institut matematiki, ekonomiki ta mehaniki, Kafedra svitovogo gospodarstva i mizhnarodnih ekonomichnih vidnosin, Odesa, 2017, s. 111-115, ISBN 978-617-7326-24-2 (Терзиев, В., Банабакова, В., Георгиев, М. Содержание и Сущность Социальной Политики. // Стратегічні орієнтири розвитку економіки України, Міжнародна науково-практична конференція 6-7 жовтня 2017 року, Міністерство освіти і науки України, Одеський національний університет імені І. І. Мечникова, Інститут математики, економіки та механіки, Кафедра світового господарства і міжнародних економічних відносин, Одеса, 2017, с. 111-115, ISBN 978-617-7326-24-2).

Terziev, V., Banabakova, V., Georgiev, M. (2017n). Problemay zanyatosti i bezrabotitsay. // Strategichni orientiri rozvitku ekonomiki Ukraïni, Mizhnarodna naukovo-praktichna konferentsiya 6-7 zhovtnya 2017 roku, Ministerstvo osviti i nauki Ukraïni, Odesykiy natsionalyniy universitet imeni I. I. Mechnikova, Institut matematiki, ekonomiki ta mehaniki, Kafedra svitovogo gospodarstva i mizhnarodnih ekonomichnih vidnosin, Odesa, 2017, s. 116-120, ISBN 978-617-7326-24-2 (Терзиев, B., Банабакова, В., Георгиев, М. Проблемы занятости и безработицы. // Стратегічні орієнтири розвитку економіки України, Міжнародна науково-практична конференція 6-7 жовтня 2017 року, Міністерство освіти і науки України, Одеський національний університет імені І. І. Мечникова, Інститут математики, економіки та механіки, Кафедра світового господарства і міжнародних економічних відносин, Одеса, 2017, с. 116-120, ISBN 978-617-7326-24-2).

Terziev, V., Banabakova, V., Georgiev, M. (2017o). Razvitie raynka truda v Bolgarii. // Strategichni orientiri rozvitku ekonomiki Ukraïni, Mizhnarodna naukovo-praktichna konferentsiya 6-7 zhovtnya 2017 roku, Ministerstvo osviti i nauki Ukraïni, Odesykiy natsionalyniy universitet imeni I. I. Mechnikova, Institut matematiki, ekonomiki ta mehaniki, Kafedra svitovogo gospodarstva i mizhnarodnih ekonomichnih vidnosin, Odesa, 2017, s. 120-124, ISBN 978-617-7326-24-2 (Терзиев, В., Банабакова, В., Георгиев, М. Развитие рынка труда в Болгарии. // Стратегічні орієнтири розвитку економіки України, Міжнародна науково-практична конференція 6-7 жовтня 2017 року, Міністерство освіти і науки України, Одеський національний університет імені І. І. Мечникова, Інститут математики, 
економіки та механіки, Кафедра світового господарства і міжнародних економічних відносин, Одеса, 2017, с. 120-124, ISBN 978-617-7326-24-2).

Terziev, V., Banabakova, V., Georgiev, M. (2017p). Razvitie kontseptsii sotsialynoy ekonomiki. // Strategichni orientiri rozvitku ekonomiki Ukraïni, Mizhnarodna naukovo-praktichna konferentsiya 6-7 zhovtnya 2017 roku, Ministerstvo osviti i nauki Ukraïni, Odesykiy natsionalyniy universitet imeni I. I. Mechnikova, Institut matematiki, ekonomiki ta mehaniki, Kafedra svitovogo gospodarstva i mizhnarodnih ekonomichnih vidnosin, Odesa, 2017, s. 125-128, ISBN 978-617-7326-24-2 (Терзиев, В., Банабакова, В., Георгиев, М. Развитие концепции социальной экономики. // Стратегічні орієнтири розвитку економіки України, Міжнародна науково-практична конференція 6-7 жовтня 2017 року, Міністерство освіти і науки України, Одеський національний університет імені I. I. Мечникова, Інститут математики, економіки та механіки, Кафедра світового господарства і міжнародних економічних відносин, Одеса, 2017, с. 125-128, ISBN 978-617-7326-24-2).

Terziev, V., Banabakova, V., Georgiev, M. (2017q). Sotsialynoy ekonomiki i sotsialynogo predprinimatelystva. // Strategichni orientiri rozvitku ekonomiki Ukraïni, Mizhnarodna naukovopraktichna konferentsiya 6-7 zhovtnya 2017 roku, Ministerstvo osviti i nauki Ukraïni, Odesykiy natsionalyniy universitet imeni I. I. Mechnikova, Institut matematiki, ekonomiki ta mehaniki, Kafedra svitovogo gospodarstva i mizhnarodnih ekonomichnih vidnosin, Odesa, 2017, s. 128-131, ISBN 978617-7326-24-2 (Терзиев, В., Банабакова, В., Георгиев, М. Социальной экономики и социального предпринимательства. // Стратегічні орієнтири розвитку економіки України, Міжнародна науковопрактична конференція 6-7 жовтня 2017 року, Міністерство освіти і науки України, Одеський національний університет імені І. І. Мечникова, Інститут математики, економіки та механіки, Кафедра світового господарства і міжнародних економічних відносин, Одеса, 2017, с. 128-131, ISBN 978-617-7326-24-2).

Terziev, V., Banabakova, V., Georgiev, M. (2017r). Sotsialynaya ekonomika i sotsialynoe predpriyatie. // Strategichni orientiri rozvitku ekonomiki Ukraïni, Mizhnarodna naukovo-praktichna konferentsiya 6-7 zhovtnya 2017 roku, Ministerstvo osviti i nauki Ukraïni, Odesykiy natsionalyniy universitet imeni I. I. Mechnikova, Institut matematiki, ekonomiki ta mehaniki, Kafedra svitovogo gospodarstva i mizhnarodnih ekonomichnih vidnosin, Odesa, 2017, s. 131-135, ISBN 978-617-7326-24-2 (Терзиев, В., Банабакова, В., Георгиев, М. Социальная экономика и социальное предприятие. // Стратегічні орієнтири розвитку економіки України, Міжнародна науково-практична конференція 6-7 жовтня 2017 року, Міністерство освіти і науки України, Одеський національний університет імені І. І. Мечникова, Інститут математики, економіки та механіки, Кафедра світового господарства і міжнародних економічних відносин, Одеса, 2017, с. 131-135, ISBN 978-617-732624-2).

Terziev, V., Banabakova, V., Georgiev, M. (2017s). Vliyanie sotsialynoy ekonomiki na zanyatosty. // Strategichni orientiri rozvitku ekonomiki Ukraïni, Mizhnarodna naukovo-praktichna konferentsiya 6-7 zhovtnya 2017 roku, Ministerstvo osviti i nauki Ukraïni, Odesykiy natsionalyniy universitet imeni I. I. Mechnikova, Institut matematiki, ekonomiki ta mehaniki, Kafedra svitovogo gospodarstva i mizhnarodnih ekonomichnih vidnosin, Odesa, 2017, s. 135-139, ISBN 978-617-7326-24-2 (Терзиев, В., Банабакова, В., Георгиев, М. Влияние социальной экономики на занятость. // Стратегічні орієнтири розвитку економіки України, Міжнародна науково-практична конференція 6-7 жовтня 2017 року, Міністерство освіти і науки України, Одеський національний університет імені I. I. Мечникова, Інститут математики, економіки та механіки, Кафедра світового господарства і міжнародних економічних відносин, Одеса, 2017, с. 135-139, ISBN 978-617-7326-24-2).

Terziev, V., Banabakova, V., Georgiev, M. (2017t). Politiki dlya sozdaniya funktsioniruyushtego raynka truda v kontekste strategii dlya ustoychivogo, inteligentnogo i vseohvatayvayushtego rosta. // Naukovopraktichnoï konferentsiï Modernizatsiya ekonomiki ta finansovoï sistemi kraïni: aktualyni problemi ta perspektivi 29-30 veresnya 2017 roku, Ministerstvo osviti i nauki Ukraïni Pridniprovsyka derzhavna akademiya budivnitstva ta arhitekturi Ekonomichniy fakulytet Université du Maine (Frantsiya) Wyższa Szkoła Biznesu - National Louis Uni-versity (Polyshta) Opolysykiy Derzhavniy Universitet (Polyshta) EF, Chastina II, Dnipro, 2017, s. 13-16, ISBN 978-966-916-365-3 (Терзиев, В., Банабакова, В., Георгиев, М. Политики для создания функционирующего рынка труда в контексте стратегии для устойчивого, интелигентного и всеохватывающего роста. // Науково-практичної конференції Модернізація економіки та фінансової системи країни: актуальні проблеми та перспективи 29-30 вересня 2017 року, Міністерство освіти і науки України Придніпровська державна академія будівництва та архітектури Економічний факультет Université du Maine (Франція) Wyższa Szkoła Biznesu - National Louis Uni-versity (Польща) Опольський Державний Університет (Польща) ЕФ, 
Частина II, Дніпро, 2017, с. 13-16, ISBN 978-966-916-365-3).

Terziev, V., Banabakova, V., Georgiev, M. (2017u). Politiki dlya sozdaniya funktsioniruyushtego raynka truda. // Naukovo-praktichnoï konferentsiï Modernizatsiya ekonomiki ta finansovoï sistemi kraïni: aktualyni problemi ta perspektivi 29-30 veresnya 2017 roku, Ministerstvo osviti i nauki Ukraïni Pridniprovsyka derzhavna akademiya budivnitstva ta arhitekturi Ekonomichniy fakulytet Université du Maine (Frantsiya) Wyższa Szkoła Biznesu - National Louis Uni-versity (Polyshta) Opolysykiy Derzhavniy Universitet (Polyshta) EF, Chastina II, Dnipro, 2017, s. 16-19, ISBN 978-966-916-365-3 (Терзиев, В., Банабакова, В., Георгиев, М. Политики для создания функционирующего рынка труда. // Науково-практичної конференції Модернізація економіки та фрінансової системи країни: актуальні проблеми та перспективи 29-30 вересня 2017 року, Міністерство освіти і науки України Придніпровська державна академія будівництва та архітектури Економічний фракультет Université du Maine (Франція) Wyższa Szkoła Biznesu - National Louis Uni-versity (Польща) Опольський Державний Університет (Польща) ЕФ, Частина II, Дніпро, 2017, с. 16-19, ISBN 978966-916-365-3).

Terziev, V., Banabakova, V., Georgiev, M. (2017v). Effektivnoe vliyanie na raynok truda. // Naukovopraktichnoï konferentsiï Modernizatsiya ekonomiki ta finansovoï sistemi kraïni: aktualyni problemi ta perspektivi 29-30 veresnya 2017 roku, Ministerstvo osviti i nauki Ukraïni Pridniprovsyka derzhavna akademiya budivnitstva ta arhitekturi Ekonomichniy fakulytet Université du Maine (Frantsiya) Wyższa Szkoła Biznesu - National Louis Uni-versity (Polyshta) Opolysykiy Derzhavniy Universitet (Polyshta) EF, Chastina II, Dnipro, 2017, s. 20-23, ISBN 978-966-916-365-3 (Терзиев, В., Банабакова, В., Георгиев, М. Эфффективное влияние на рынок труда. // Науково-практичної конференції Модернізація економіки та фрінансової системи країни: актуальні проблеми та перспективи 29-30 вересня 2017 року, Міністерство освіти і науки України Придніпровська державна академія будівництва та архітектури Економічний фракультет Université du Maine (Франція) Wyższa Szkoła Biznesu - National Louis Uni-versity (Польща) Опольський Державний Університет (Польща) ЕФ, Частина II, Дніпро, 2017, с. 20-23, ISBN 978-966-916-365-3).

Terziev, V., Georgiev, G., Georgiev, M. (2017w). Interpersonal styles for resolving conflicts in the organization. // World scientific extent, Collection of scientific articles Scientific journal «Economics and finance». Agenda Publishing House, United Kingdom, 2017, pp. 295-300, ISBN 978-0-9955865-36.

Terziev, V., Georgiev, G., Georgiev, M. (2017x). Possible solutions for management of stress and conflicts in the organization. // World scientific extent, Collection of scientific articles, Scientific journal «Economics and finance». Agenda Publishing House, United Kingdom, 2017, pp. 300-305, ISBN 9780-9955865-3-6.

Terziev, V., Georgiev, G., Georgiev, M. (2017y). Occurrence of labor and conflict conflicts in the organization, decisions at a mobbing situation. // World scientific extent, Collection of scientific articles, Scientific journal «Economics and finance». Agenda Publishing House, United Kingdom, 2017, pp. 305-311, ISBN 978-0-9955865-3-6.

Terziev, V., Georgiev, G., Georgiev, M. (2017z). Recognizing mobbing and limitation of its activities in the organization. // World scientific extent, Collection of scientific articles, Scientific journal «Economics and finance». Agenda Publishing House, United Kingdom, 2017, pp. 311-317, ISBN 978-0-9955865-36.

Terziev, V., Georgiev, G., Georgiev, M. (2017aa). Methods for resolving conflicts and managing stress at the workplace. // World scientific extent, Collection of scientific articles, Scientific journal «Economics and finance». Agenda Publishing House, United Kingdom, 2017, pp. 317-324, ISBN 978-0-9955865-3-6.

Terziev, V., Georgiev, G., Georgiev, M. (2017ab). Management styles in the organization. // World scientific extent, Collection of scientific articles, Scientific journal «Economics and finance». Agenda Publishing House, United Kingdom, 2017, pp. 324-329, ISBN 978-0-9955865-3-6.

Terziev, V., Georgiev, G., Georgiev, M. (2017ac). Strategic concept of the company. // World scientific extent, Collection of scientific articles, Scientific journal «Economics and finance». Agenda Publishing House, United Kingdom, 2017, pp. 329-335, ISBN 978-0-9955865-3-6.

Terziev, V., Georgiev, M. (2018). Efficient management as optimization of the organization. // Proceedings of INTCESS2018- 5th International Conference on Education and Social Sciences 5-7 February 2018Istanbul, Turkey, International Organization Center of Academic Research, www.ocerints.org, Istanbul, Turkey, 2018, pp. 452-461, ISBN: 978-605-82433-2-3. 
IJASOS- International E-Journal of Advances in Social Sciences, Vol. IV, Issue 12, December 2018

Terziev, V., Georgiev, M. (2018a). Efficient management as optimization of the organization. // IJAEDUInternational E-Journal of Advances in Education, April 2018, International Organization Center of Academic Research, www.ocerints.org, Istanbul, Turkey, 2018, pp. 6-15, 4, 2018, N 10, e-ISSN: 2411 183X.

Terziev, V., Banabakova, V., Stefanov, S., Georgiev, M. (2018b). Problems of stimulation of the staff in the conditions of market economy. // Knowledge - International journal scientific papers, promoted in Vrnjacka Banja, Serbia 16-18.03.2018, Institute of Knowledge Management- Skopje, 22, 2018, N 1, pp. 267-272, ISSN 1857-923X (for e - version), ISSN 2545-4439 (for printed version).

Terziev, V., Banabakova, V., Stefanov, S., Georgiev, M. (2018c). Internal-organizational training as a process for continuing education. // Knowledge - International journal scientific papers, promoted in Vrnjacka Banja, Serbia 16-18.03.2018, , Institute of Knowledge Management- Skopje, 22, 2018, N 1, pp. 79-87, ISSN 1857-923X (for e - version), ISSN 2545-4439 (for printed version).

Terziev, V., Banabakova, V., Stefanov. S., Georgiev, M. (2018d). Difficulties in the division of powers between the co-workers. // Knowledge - International journal scientific papers, promoted in Vrnjacka Banja, Serbia 16-18.03.2018, Institute of Knowledge Management- Skopje, 22, 2018, N 2, pp. 553559, ISSN 1857-923X (for e - version), ISSN 2545-4439 (for printed version).

Terziev, V., Banabakova, V., Georgiev, M. (2018e). Modern dimensions of social policies. // International journal scientific papers Vol 23.4 Promoted in Budva, Montenegro 24-27.05.2018, IKM - Skopje, 23, 2017, N 4, pp. 935-944, ISSN 1857-923X (for e-version) ISSN 2545- 4439 (for printed version).

Terziev, V., Banabakova, V., Georgiev, M. (2018f). Social support as part of social policy. // International journal scientific papers Vol 23.4 Promoted in Budva, Montenegro 24-27.05.2018, IKM - Skopje, 23, 2017, N 4, pp. 973-980, ISSN 1857-923X (for e-version) ISSN 2545 - 4439 (for printed version). 